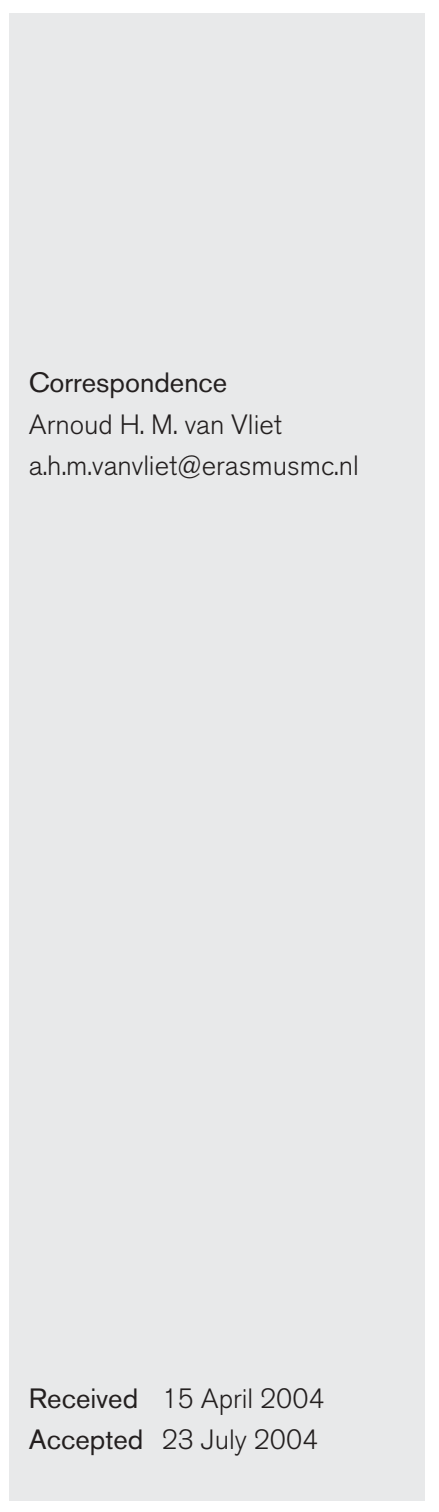

\section{Role of the $r d x A$ and frxA genes in oxygen-dependent metronidazole resistance of Helicobacter pylori}

\author{
Monique M. Gerrits, ${ }^{1}$ Egbert-Jan van der Wouden, ${ }^{2}$ Dorine A. Bax, \\ Anton A. van Zwet, ${ }^{3}$ Arnoud H. M. van Vliet, ${ }^{1}$ Albertine de Jong, ${ }^{3}$ \\ Johannes G. Kusters, ${ }^{1}$ Jaap C. Thijs ${ }^{2}$ and Ernst J. Kuipers ${ }^{1}$ \\ ${ }^{1}$ Department of Gastroenterology and Hepatology, Erasmus MC-University Medical Center, \\ Rotterdam, The Netherlands \\ ${ }^{2}$ Department of Internal Medicine, Bethesda Hospital, Hoogeveen, The Netherlands \\ ${ }^{3}$ Regional Public Health Laboratory Groningen/Drenthe, Groningen, The Netherlands
}

\section{INTRODUCTION}

Helicobacter pylori is a spiral-shaped, Gram-negative bacterium that colonizes the stomach of approximately half the world's population (Blaser \& Berg, 2001). Colonization with $H$. pylori is the most common cause of chronic active gastritis and peptic ulcer disease, and is strongly associated with the development of gastric cancer and gastric lymphoma. Unless treated with antibiotics, $H$. pylori colonization tends to persist for life. Cure of $H$. pylori infection results in ulcer healing and may reduce the risk of gastric cancer and gastric lymphoma development (Sugiyama et al., 2002; Wilhelmsen

Abbreviations: $\mathrm{Mtz}^{\mathrm{R}}$, metronidazole-resistant; RAPD, random amplified polymorphic DNA.

The GenBank accession numbers for the $r d x A$ and frxA gene sequences of seven metronidazole-resistant $H$. pylori strains are AY568322AY568328 and AY568330-AY568336.
\& Berstad, 1994). In vitro, H. pylori is susceptible to the majority of antibiotics, but for effective treatment a combination of drugs is required (Debets-Ossenkopp et al., 1999b). Currently used anti- $H$. pylori therapies often consist of two antibiotics with a proton pump inhibitor and/or a bismuth component (Malfertheiner et al., 2002). Metronidazole [1(2-hydroxyethyl)-2-methyl-5-nitroimidazole] is a key component of such combination therapies (Malfertheiner et al., 2002; van der Hulst et al., 1996).

In Western Europe it has been estimated that $20-45 \%$ of the H. pylori isolates are metronidazole-resistant $\left(\mathrm{Mtz}^{\mathrm{R}}\right)$ (Glupczynski et al., 2001; Lopez-Brea et al., 2001). This percentage is even higher in developing countries and immigrant populations (Falsafi et al., 2004; Loffeld \& Fijen, 2003). Although there are conflicting reports concerning the clinical relevance of metronidazole resistance in $H$. pylori, metronidazole resistance reduces the efficacy of metronida- 
zole-containing regimens significantly (Jenks et al., 1999a; van der Wouden et al., 1999), but surprisingly does not render them inactive.

Metronidazole is a prodrug that needs to be activated by a reduction of the nitro group that is attached to the imidazole ring. This reduction step leads to the production of DNAdamaging nitroso- and hydroxylamine-compounds. Exposure to these toxic compounds causes DNA damage, and subsequently results in the death of the bacterium. In $H$. pylori, it is believed that reduction of metronidazole is mainly mediated by an oxygen-insensitive NADPH nitroreductase (RdxA) (Goodwin et al., 1998; Sisson et al., 2002), but recently it has been shown that the NADPH-flavin-oxidoreductase (FrxA) also participates in the reduction of metronidazole (Jeong et al., 2000).

In H. pylori, metronidazole resistance is primarily associated with mutational inactivation of the $r d x A$ gene (DebetsOssenkopp et al., 1999a; Goodwin et al., 1998; Jenks et al., 1999 b). However, recently it has been demonstrated that inactivation of the frxA gene also confers metronidazole resistance, either alone or in association with the $r d x A$ gene (Jeong et al., 2000; Kwon et al., 2000a, b, 2001). Whether mutational inactivation of these two enzymes accounts for metronidazole resistance in all clinical isolates is still being debated (Bereswill et al., 2003; Chisholm \& Owen, 2004; Kwon et al., 2000a), but they most likely reflect the two major contributing factors.

The discrepancy between the in vitro resistance to metronidazole and treatment outcome may be explained by the antimicrobial activity of other components in the regimens and/or duration and doses of the therapy (van der Wouden et al., 1999). Apart from these factors, it is likely that low oxygen tension in the gastric environment may also be involved
(Smith \& Edwards, 1995), since low oxygen conditions affect the activity of metronidazole-reducing enzymes (Jenks \& Edwards, 2002). As in vitro $\mathrm{Mtz}^{\mathrm{R}} H$. pylori isolates become susceptible to metronidazole after a short period of anaerobic incubation (Cederbrant et al., 1992; Smith \& Edwards, 1995), it has been suggested that the FrxA protein and/or other ferredoxin and flavin reductases may contribute to the activation of metronidazole under these conditions (Goodwin et al., 1998; Kaihovaara et al., 1998).

In this study the role of null mutations in the $r d x A$ and $f r x A$ genes on the reversibility of metronidazole resistance under low oxygen conditions was determined.

\section{METHODS}

Strains and growth conditions. $H$. pylori isolates used in this study and their respective $r d x A$ and $f r x A$ gene status inferred from DNA sequences are listed in Table 1 . The $H$. pylori isolates were routinely grown on Dent plates as described previously (Gerrits et al., 2002b). Broth cultures were grown in Brucella broth supplemented with $3 \%$ newborn calf serum (BBN). All cultures were incubated either under microaerophilic $\left(5 \% \mathrm{O}_{2}, 10 \% \mathrm{CO}_{2}\right.$ and $\left.85 \% \mathrm{~N}_{2}\right)$ or anaerobic conditions $\left(10 \% \mathrm{H}_{2}, 5 \% \mathrm{CO}_{2}\right.$ and $\left.85 \% \mathrm{~N}_{2}\right)$ at $37^{\circ} \mathrm{C}$. The anaerobic culture condition was created using the Anoxomat (Mart) in combination with a catalyst. Escherichia coli strain DH5 $\alpha$ MCR (Life Technologies) was grown on Luria-Bertani agar plates (Sambrook et al., 1989) for $24 \mathrm{~h}$ at $37^{\circ} \mathrm{C}$ in an aerobic environment. Selection of E. coli transformed with pGEM-T Easy clones was performed on LB-agar plates containing ampicillin to a final concentration $100 \mu \mathrm{g} \mathrm{ml} \mathrm{m}^{-1}$ (Sigma-Aldrich).

DNA manipulation. DNA manipulations were performed according to standard protocols (Sambrook et al., 1989). Oligonucleotides (Table 2; Isogen), PCR-core system I (Promega) and pGEM-T Easy vector (Promega) were used according to the manufacturer's recommendations. Plasmid DNA was isolated with Wizard Plus SV Minipreps DNA Purification System (Promega) according to the manufacturer's in-

Table 1. Mtz ${ }^{\mathrm{R}} H$. pylori strains and their $r d x A$ and $\operatorname{fr} x A$ gene status

\begin{tabular}{|lccc|}
\hline H. pylori isolate & MIC $\left(\mu \mathbf{g ~ m l}^{-1}\right)^{*}$ & \multicolumn{2}{c|}{ GenBank accession no. } \\
\cline { 3 - 4 } & & $\boldsymbol{r d x A}$ (HP0954) & frxA (HP0642) \\
\hline Truncated $r d x$ A gene & & & \\
BH9711-176 & 24 & AY568322 & AY568330 \\
DM9735-58 & $>256$ & AY568328 & AY568336 \\
Truncated $f r x A$ gene & & & \\
BH9713-141 & $>256$ & AY568323 & AY568331 \\
DM9642-108 & $>256$ & AY568325 & AY568333 \\
DM9716-140 & 32 & AY568326 & AY568334 \\
Truncated $r d x A$ and $f r x A$ genes & & & AY568332 \\
BH9714-19 & 128 & AY568324 & AY568335 \\
DM9727-179 & 192 & Debets-Ossenkopp et al. (1999a) & Kwon et al. (2000b) \\
ATCC $43504^{\mathrm{T}}$ & $>256$ & & \\
\hline
\end{tabular}

${ }^{\star}$ MICs shown are means of results from three independent experiments. The isolates were considered to be resistant when the MIC of metronidazole was $\geqslant 8 \mu \mathrm{g} \mathrm{ml}^{-1}$ (Gerrits et al., 2002b). 
Table 2. Oligonucleotides used in this study

Oligonucleotides used for amplification were based on the published genome sequence of $H$. pylori strain 26695 (Tomb et al., 1997).

\begin{tabular}{|cl|}
\hline $\begin{array}{l}\text { Gene/primer } \\
\text { name }\end{array}$ & \multicolumn{1}{c|}{ Nucleotide sequence $\left(\mathbf{5}^{\prime} \rightarrow \mathbf{3}^{\prime}\right)$} \\
\hline $\boldsymbol{r d x} \boldsymbol{A}(\mathbf{H P 0 9 5 4})$ & \\
RdxA-F1 & GCTGATTGTGGTTTATGGTTTGG \\
RdxA-F2 & TTGGATCAAGAAAAAAGAAGACAATTATTAA \\
RdxA-F3 & GCTGATTGTGGTTTATGGTTTGG \\
RdxA-F4 & GAGAGCCGGACAGCCAAATG \\
RdxA-R1 & CACCCCTAAAAGAGCGATTAAAACC \\
RdxA-R2 & GCAAGAATGGCGCTCGTT \\
RdxA-R3 & CCCACAGCGATATAGCATTG \\
$\boldsymbol{f r} \boldsymbol{x}($ HP0642) & \\
FrxA-F1 & GGATATGGCAGCCGTTTATCATT \\
FrxA-R1 & GAATAGGCATCATTTAAGAGATTA \\
FrxA-R2 & TGGTTCAAGCCCGATTGAAG \\
\hline
\end{tabular}

structions. Sequencing of the obtained plasmid and PCR products was performed by Baseclear (Leiden, The Netherlands).

Random amplified polymorpic DNA (RAPD) fingerprinting. RAPD analysis of chromosomal DNA was performed with three independent primers, 1254, D11344 and D9355 as described before by Akopyanz et al. (1992). RAPD products were separated in $2 \%$ agarose gels containing $0.5 \mu$ g ethidium bromide $\mathrm{ml}^{-1}$ (Promega).

The influence of the length of anaerobic incubation on antibiotic resistance. MIC values were routinely analysed by E-test (AB Biodisk) (Gerrits et al., 2002b) or agar dilution (Trieber \& Taylor, 2002). The plates were incubated under anaerobic conditions for $0,0 \cdot 25,0 \cdot 5,1,2,4$ and $8 \mathrm{~h}$ and subsequently incubated for 3 days at $37^{\circ} \mathrm{C}$ under microaerophilic conditions, according to the guidelines of the National Committee for Clinical Laboratory Standards. The isolates were considered resistant when the MICs of amoxycillin $\geqslant 8 \mu \mathrm{g} \mathrm{ml}^{-1}$, clarithromycin $\geqslant 2 \mu \mathrm{g} \mathrm{ml}^{-1}$, metronidazole $\geqslant 8 \mu \mathrm{g} \mathrm{ml}^{-1}$ and tetracycline $\geqslant 4 \mu \mathrm{g}$ $\mathrm{ml}^{-1}$ (Gerrits et al., 2002b). As controls, resistant strains were included for each tested antibiotic (Debets-Ossenkopp et al., 1998; Gerrits et al., 2002a, b). All MIC determinations were performed in triplicate.

The influence of chloramphenicol on metronidazole resistance during anaerobic incubation. Bacteria freshly grown on Dent plates were harvested and inoculated in BBN to a cell density of $\sim 1 \times 10^{7}$ c.f.u. $\mathrm{ml}^{-1}$, and incubated overnight with gentle agitation under microaerophilic conditions. Fumaric acid (Sigma-Aldrich, final concentration $0 \cdot 1 \%$ ) was then added to the overnight culture to facilitate the generation of anaerobic conditions (Jenks et al., 1999b). The culture was then split into $10 \mathrm{ml}$ portions and when indicated supplemented with metronidazole (Sigma-Aldrich, final concentration $16 \mu \mathrm{g} \mathrm{ml}^{-1}$ ) and/or chloramphenicol (Sigma-Aldrich, final concentration $10 \mu \mathrm{g}$ $\mathrm{ml}^{-1}$ ). Subsequently, the cultures were incubated under microaerophilic or anaerobic conditions for 0, 2, 4,6 and $8 \mathrm{~h}$. At each time point $1 \mathrm{ml}$ of the broth was taken and washed twice with PBS to remove the antibiotics. In order to determine the number of viable bacteria, $50 \mu \mathrm{l}$ of undiluted suspension and $10^{-1}, 10^{-2}, 10^{-3}$ and $10^{-4}$ dilutions were plated on Columbia agar plates containing $7 \%$ lysed horse blood and incubated under microaerophilic conditions. When present, colonies were counted and data are expressed as c.f.u. $\mathrm{ml}^{-1}$.

\section{RESULTS AND DISCUSSION}

\section{Effect of anaerobic incubation on MIC}

To evaluate the effect of anaerobic incubation on the MIC of metronidazole, seven $\mathrm{Mtz}^{\mathrm{R}} H$. pylori clinical isolates and the $\mathrm{Mtz}^{\mathrm{R}}$ H. pylori reference strain ATCC $43504^{\mathrm{T}}$ were selected for this study. To ensure that these strains represented different isolates, RAPD fingerprinting was performed with primers D11344 (Fig. 1), 1254 and D9355 (data not shown). All strains gave different profiles with each of the three primers, indicating they represent unrelated isolates. These seven $\mathrm{Mtz}^{\mathrm{R}}$ isolates and reference strain ATCC $43504^{\mathrm{T}}$ were incubated in microaerophilic and anaerobic conditions, and the MIC of metronidazole was determined by E-test and agar dilution. Under standard microaerophilic culture conditions, the MIC of metronidazole for the eight isolates, as determined by E-test, ranged from 24 to $>256 \mu \mathrm{g} \mathrm{ml}^{-1}$, (Table 3). These MICs for metronidazole decreased under anaerobic conditions. After $4 \mathrm{~h}$ of anaerobic incubation, the MIC values for metronidazole dropped below the breakpoint $\left(8 \mu \mathrm{g} \mathrm{ml}^{-1}\right)$ for three of the eight isolates, and after $8 \mathrm{~h}$, all $\mathrm{Mtz}^{\mathrm{R}}$ isolates had become metronidazole-susceptible (Table 3). In contrast to metronidazole, the MICs for amoxycillin, clarithromycin and tetracycline were stable during anaerobic incubation (data not shown). There were no clear differences found in the MIC values between the E-test and agar dilution.

\section{Effect of metronidazole and anaerobic incubation on cell viability}

To determine the effect of metronidazole and anaerobic incubation on cell viability, all seven $\mathrm{Mtz}^{\mathrm{R}} \mathrm{H}$. pylori isolates and the $\mathrm{Mtz}^{\mathrm{R}}$ reference strain ATCC $43504^{\mathrm{T}}$ were cultured in broth under microaerophilic and anaerobic conditions

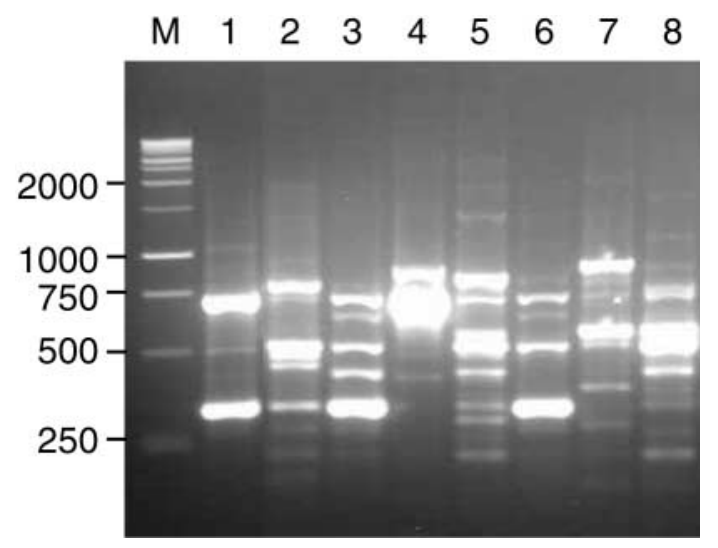

Fig. 1. The $H$. pylori isolates used in this study represent unrelated isolates, as shown by RAPD-PCR. DNA isolated from the $\mathrm{Mtz}^{\mathrm{R}}$ isolates was amplified with primer D1 1344 according to standard procedures (Akopyanz et al., 1992). The RAPD-PCR products were separated on a $2.0 \%$ agarose gel and stained with ethidium bromide. Lane $1, \mathrm{H}$. pylori reference strain ATCC 43504', lanes 2-8, BH9711-176, BH9713-141, BH9714-19, DM9735-58, DM9727-179, DM9642108 and DM9716-140, respectively. M, 1 kb marker (Promega). 
Table 3. The effect of anaerobic incubation on metronidazole resistance

MICs shown are means of results from three independent experiments. The isolates were considered to be resistant when the MIC of metronidazole was $\geqslant 8 \mu \mathrm{g} \mathrm{ml}^{-1}$ (Gerrits et al., 2002b). $\mathrm{T}_{0}$, time point zero, start point; $\mathrm{T}_{2}, \mathrm{~T}_{4}$ and $\mathrm{T}_{8}$, after 2,4 and $8 \mathrm{~h}$ of anaerobic incubation, respectively.

\begin{tabular}{|lrrrl|}
\hline H. pylori isolates & \multicolumn{5}{c|}{ MIC $\left(\mu \mathrm{g} \mathrm{ml}^{-\mathbf{1}}\right)$} \\
\cline { 2 - 5 } & $\mathrm{T}_{\mathbf{0}}$ & $\mathrm{T}_{\mathbf{2}}$ & $\mathrm{T}_{\mathbf{4}}$ & \multicolumn{1}{c|}{$\mathrm{T}_{\mathbf{8}}$} \\
\hline Truncated $r d x$ A gene & 24 & 16 & 12 & 3 \\
$\quad$ BH9711-176 & $>256$ & 32 & 4 & $0 \cdot 75$ \\
DM9735-58 & & & & \\
Truncated frxA gene & $>256$ & 48 & 24 & 3 \\
BH9713-141 & $>256$ & 64 & 24 & 2 \\
DM9642-108 & 32 & 8 & 4 & $0 \cdot 75$ \\
DM9716-140 & & & & \\
Truncated $r d x A$ and frxA genes & 128 & 48 & 12 & 4 \\
BH9714-19 & 192 & 96 & 16 & $0 \cdot 5$ \\
DM9727-179 & $>256$ & 48 & 6 & $0 \cdot 25$ \\
ATCC $43504^{\mathrm{T}}$ & & & \\
\hline
\end{tabular}

either in the presence or absence of $16 \mu \mathrm{g}$ metronidazole $\mathrm{ml}^{-1}$, and at different time intervals the amount of viable bacteria (c.f.u. $\mathrm{ml}^{-1}$ ) was determined. Under standard microaerophilic conditions, the amount of viable cells for all tested $\mathrm{Mtz}^{\mathrm{R}}$ isolates varied between $10^{6}$ and $10^{7}$ c.f.u. $\mathrm{ml}^{-1}$, and there were no significant differences observed in c.f.u. $\mathrm{ml}^{-1}$ between the cultures with and without metronidazole (Fig. 2). Similar data were obtained for the cultures without metronidazole that were incubated anaerobically

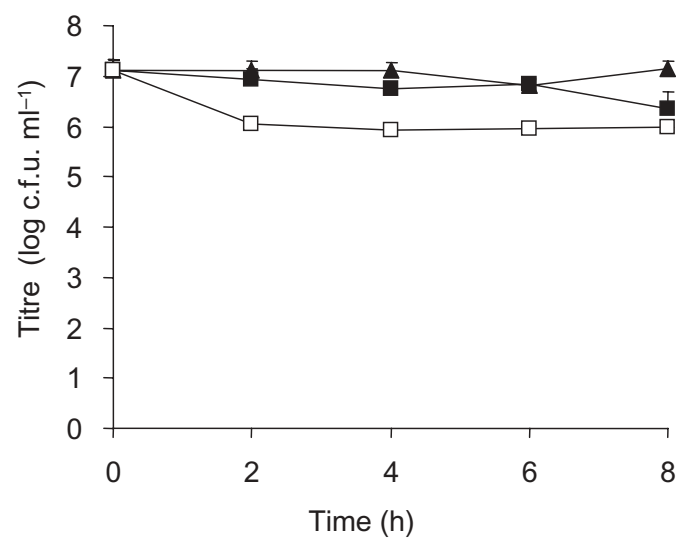

Fig. 2. The influence of metronidazole and anaerobic incubation on cell viability. $H$. pylori was grown microaerophilically in the presence (A) and absence (ם) of $16 \mu \mathrm{g}$ metronidazole $\mathrm{ml}^{-1}$, and anaerobically ( $\square$ ). At different time points the c.f.u. $\mathrm{ml}^{-1}$ was determined. Results shown are a representative example of one of the $\mathrm{Mtz}^{\mathrm{R}}$ isolates, $\mathrm{BH} 9714-19$, and are the means ( $\mathrm{SD}$ ) of two independent experiments performed in duplicate.
(Fig. 2). This suggests that neither the incubation with metronidazole nor anaerobic growth conditions alone affect the cell viability of the $\mathrm{Mtz}^{\mathrm{R}}$ isolates.

However, under anaerobic conditions in the presence of metronidazole, the amount of viable cells dropped more than 1000 -fold when the $\mathrm{Mtz}^{\mathrm{R}}$ isolates were incubated for $4 \mathrm{~h}$ anaerobically, and after $8 \mathrm{~h}$ of anaerobic incubation in the presence of metronidazole there were no viable cells present (Fig. 3). Since there were no differences in cell viability or time-course observed between the $\mathrm{Mtz}^{\mathrm{R}}$ isolates containing mutations that resulted in either a truncated $\mathrm{RdxA}$ protein or FrxA protein, or a truncation in both, this suggests that neither the $r d x A$ gene nor the frxA gene is involved in the reversibility of metronidazole resistance in $H$. pylori.

\section{Effect of de novo protein synthesis on reversibility of metronidazole resistance during anaerobic incubation}

To determine whether $H$. pylori requires de novo protein synthesis for the reversibility of metronidazole resistance, all experiments were repeated in broth in the presence of the bacterial protein synthesis inhibitor chloramphenicol $(10 \mu \mathrm{g}$ $\mathrm{ml}^{-1}$ ). This concentration of chloramphenicol was optimized previously, and its effects on the inhibition of the protein synthesis and cell viability are known (Kusters et al., 1997). When the $\mathrm{Mtz}^{\mathrm{R}}$ isolates were incubated anaerobically in the presence of metronidazole and chloramphenicol, cell viability was reduced (Fig. 4). As there was no significant difference in cell viability between the cultures with and

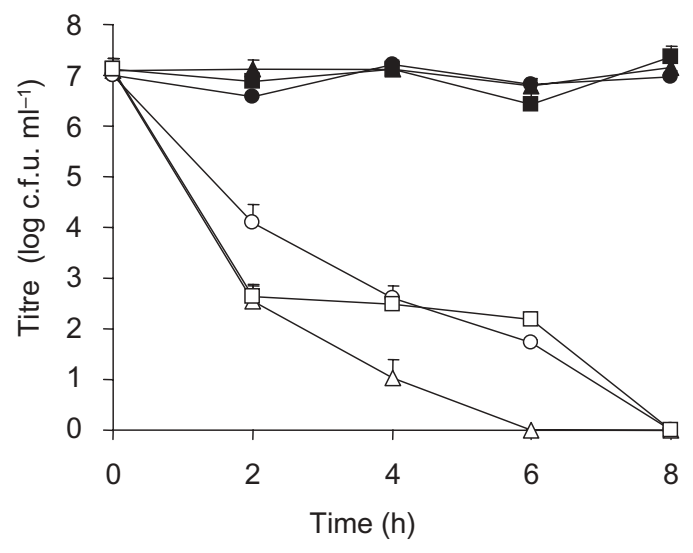

Fig. 3. Involvement of the $r d x A$ and/or frxA gene in the reversibility of metronidazole resistance under anaerobic conditions. H. pylori was grown in microaerophilic (filled symbols) and anaerobic (open symbols) conditions in the presence of $16 \mu$ g metronidazole $\mathrm{ml}^{-1}$, and the c.f.u. $\mathrm{ml}^{-1}$ were determined. Results shown are for representative examples of the $\mathrm{Mtz}^{\mathrm{R}}$ isolates tested. $\mathbf{\square} / \square, \mathrm{BH} 9714-19$ (containing mutations resulting in truncated $\operatorname{RdxA}$ and FrxA proteins); $\mathbf{\Delta} / \triangle$, DM9735-58 (containing mutations resulting in a truncated $\mathrm{RdxA}$ ); / $\mathrm{O}, \mathrm{BH} 9713-141$ (containing mutations resulting in a truncated FrxA). Results shown are the means $( \pm S D)$ of two independent experiments performed in duplicate. 


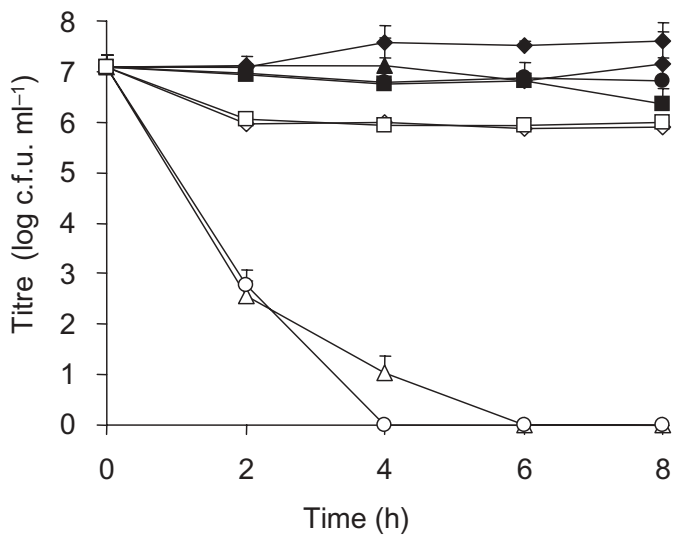

Fig. 4. The effect of blocking de novo protein synthesis on the reversibility of metronidazole resistance. $H$. pylori was grown in broth either with or without metronidazole $\left(16 \mu \mathrm{g} \mathrm{ml}^{-1}\right)$ and/or chloramphenicol $\left(10 \mu \mathrm{g} \mathrm{ml}^{-1}\right)$ under microaerophilic (filled symbols) or anaerobic (open symbols) conditions. Results shown are for a representative example (strain $\mathrm{BH} 9714-19)$ of the $\mathrm{Mtz}^{\mathrm{R}}$ isolates tested. $\boldsymbol{\square} / \square$, Control; $\boldsymbol{\Delta} / \triangle$, with metronidazole; $\Delta / \diamond$, with chloramphenicol; $ノ \bigcirc$, with metronidazole and chloramphenicol. Results shown are the means $( \pm S D)$ of two independent experiments performed in duplicate.

without chloramphenicol these results indicate that factors that are involved in the reversibility of metronidazole resistance are already present under microaerophilic conditions. De novo protein synthesis is not required for this phenomenon.

\section{Implications of experimental data}

Metronidazole, a nitroimidazole, is administered as a prodrug that is activated by the reduction of the nitro group that is attached to an imidazole ring (Edwards, 1986). Since oxygen has a higher reduction potential than metronidazole, this reduction step works out most effectively in an environment with low oxygen tension, such as anaerobic cells and protozoa (Jenks \& Edwards, 2002). Surprisingly, the drug was also found to be active against the microaerophilic pathogen $H$. pylori (Lacey et al., 1993). In many strictly anaerobic bacteria, the activation of metronidazole is mediated by the pyruvate : ferredoxin oxidoreductase complex (Smith et al., 1998). In H. pylori, this function might be fulfilled by the electron carriers, RdxA (HP0954), FrxA (HP0642), ferredoxin (FdxA, HP0277), flavodoxin (FldA, HP1161), pyruvate:ferredoxin oxidoreductase (PorD, HP1109) and 2-oxoglutarate ferredoxin oxidoreductase (OorD, HP0588). As mutations of the latter four nitroreductases were found to be lethal (Jeong et al., 2000; Kwon et al., 2000a), we only tested the involvement of the $r d x A$ and frxA genes. In contrast with the findings under normal microaerophilic conditions (Kwon et al., 2000b; Sisson et al., 2002), we showed that neither the $r d x A$ nor the frxA gene is required for the activation of metronidazole under low oxygen conditions, since strains with one or both genes inactivated still become susceptible to metronidazole under anaerobic conditions.

As $\mathrm{Mtz}^{\mathrm{R}} \mathrm{H}$. pylori isolates lose their resistance to metronidazole after exposure to short periods of anaerobiosis in vitro (Cederbrant et al., 1992; Smith \& Edwards, 1995), it has been suggested that this reversibility is mediated by compensatory metabolic pathways that are induced under anaerobic conditions (Jenks \& Edwards, 2002; Smith \& Edwards, 1997). This hypothesis is not supported by our data obtained using the protein synthesis inhibitor chloramphenicol. The loss of metronidazole resistance is mediated by a pre-existing mechanism that functions under anaerobic conditions, and is not dependent on de novo protein synthesis when $H$. pylori is exposed to these conditions. Since our data excluded the role of the RdxA and FrxA proteins in this process, we assume that in $\mathrm{H}$. pylori metronidazole is reduced by one of the other known nitroreductases.

In summary, $\mathrm{Mtz}^{\mathrm{R}} H$. pylori isolates become fully metronidazole-susceptible at low oxygen conditions, and this does not require de novo protein synthesis. This reversibility in metronidazole resistance also occurred in $\mathrm{H}$. pylori isolates that contained mutations in the $r d x A$ and/or frxA genes. Exposure of $H$. pylori to such low oxygen conditions in the gastric mucosa or gastric pit is likely to induce reduction of metronidazole, and thus assist in the eradication of $\mathrm{Mtz}^{\mathrm{R}} H$. pylori.

\section{ACKNOWLEDGEMENTS}

The authors would like to thank Andy van Oosterhout for technical assistance.

\section{REFERENCES}

Akopyanz, N., Bukanov, N. O., Westblom, T. U. \& Berg, D. E. (1992). PCR-based RFLP analysis of DNA sequence diversity in the gastric pathogen Helicobacter pylori. Nucleic Acids Res 20, 6221-6225.

Bereswill, S., Krainick, C., Stahler, F., Herrmann, L. \& Kist, M. (2003). Analysis of the $r d x A$ gene in high-level metronidazole-resistant clinical isolates confirms a limited use of $r d x A$ mutations as a marker for prediction of metronidazole resistance in Helicobacter pylori. FEMS Immunol Med Microbiol 36, 193-198.

Blaser, M. J. \& Berg, D. E. (2001). Helicobacter pylori genetic diversity and risk of human disease. J Clin Invest 107, 767-773.

Cederbrant, G., Kahlmeter, G. \& Ljungh, A. (1992). Proposed mechanism for metronidazole resistance in Helicobacter pylori. J Antimicrob Chemother 29, 115-120.

Chisholm, S. A. \& Owen, R. J. (2004). Frameshift mutations in frxA occur frequently and do not provide a reliable marker for metronidazole resistance in UK isolates of Helicobacter pylori. J Med Microbiol 53, $135-140$.

Debets-Ossenkopp, Y. J., Brinkman, A. B., Kuipers, E. J., Vandenbroucke-Grauls, C. M. \& Kusters, J. G. (1998). Explaining the bias in the $23 \mathrm{~S}$ rRNA gene mutations associated with clarithromycin resistance in clinical isolates of Helicobacter pylori. Antimicrob Agents Chemother 42, 2749-2751.

Debets-Ossenkopp, Y. J., Pot, R. G., van Westerloo, D. J., Goodwin, A., Vandenbroucke-Grauls, C. M., Berg, D. E., Hoffman, P. S. \& Kusters, 
J. G. (1999a). Insertion of mini-IS605 and deletion of adjacent sequences in the nitroreductase $(r d x A)$ gene cause metronidazole resistance in Helicobacter pylori NCTC11637. Antimicrob Agents Chemother 43, 2657-2662.

Debets-Ossenkopp, Y. J., Herscheid, A. J., Pot, R. G., Kuipers, E. J., Kusters, J. G. \& Vandenbroucke-Grauls, C. M. (1999b). Prevalence of Helicobacter pylori resistance to metronidazole, clarithromycin, amoxycillin, tetracycline and trovafloxacin in The Netherlands. J Antimicrob Chemother 43, 511-515.

Edwards, D. I. (1986). Reduction of nitroimidazoles in vitro and DNA damage. Biochem Pharmacol 35, 53-58.

Falsafi, T., Mobasheri, F., Nariman, F. \& Najafi, M. (2004). Susceptibilities to different antibiotics of Helicobacter pylori strains isolated from patients at the pediatric medical center of Tehran, Iran. J Clin Microbiol 42, 387-389.

Gerrits, M. M., Schuijffel, D., van Zwet, A. A., Kuipers, E. J., Vandenbroucke-Grauls, C. M. \& Kusters, J. G. (2002a). Alterations in penicillin-binding protein $1 \mathrm{~A}$ confer resistance to $\beta$-lactam antibiotics in Helicobacter pylori. Antimicrob Agents Chemother 46, 2229-2233.

Gerrits, M. M., de Zoete, M. R., Arents, N. L., Kuipers, E. J. \& Kusters, J. G. (2002b). $16 \mathrm{~S}$ rRNA mutation-mediated tetracycline resistance in Helicobacter pylori. Antimicrob Agents Chemother 46, 2996-3000.

Glupczynski, Y., Megraud, F., Lopez-Brea, M. \& Andersen, L. P. (2001). European multicentre survey of in vitro antimicrobial resistance in Helicobacter pylori. Eur J Clin Microbiol Infect Dis 20, 820-823.

Goodwin, A., Kersulyte, D., Sisson, G., Veldhuyzen van Zanten, S. J., Berg, D. E. \& Hoffman, P. S. (1998). Metronidazole resistance in Helicobacter pylori is due to null mutations in a gene $(r d x A)$ that encodes an oxygen-insensitive NADPH nitroreductase. Mol Microbiol 28, 383-393.

Jenks, P. J. \& Edwards, D. I. (2002). Metronidazole resistance in Helicobacter pylori. Int J Antimicrob Agents 19, 1-7.

Jenks, P. J., Labigne, A. \& Ferrero, R. L. (1999a). Exposure to metronidazole in vivo readily induces resistance in Helicobacter pylori and reduces the efficacy of eradication therapy in mice. Antimicrob Agents Chemother 43, 777-781.

Jenks, P. J., Ferrero, R. L. \& Labigne, A. (1999b). The role of the $r d x A$ gene in the evolution of metronidazole resistance in Helicobacter pylori. J Antimicrob Chemother 43, 753-758.

Jeong, J. Y., Mukhopadhyay, A. K., Dailidiene, D. \& 20 other authors (2000). Sequential inactivation of $r d x$ A (HP0954) and frxA (HP0642) nitroreductase genes causes moderate and high-level metronidazole resistance in Helicobacter pylori. J Bacteriol 182, 5082-5090.

Kaihovaara, P., Hook-Nikanne, J., Uusi-Oukari, M., Kosunen, T. U. \& Salaspuro, M. (1998). Flavodoxin-dependent pyruvate oxidation, acetate production and metronidazole reduction by Helicobacter pylori. J Antimicrob Chemother 41, 171-177.

Kusters, J. G., Gerrits, M. M., Van Strijp, J. A. \& Vandenbroucke-Grauls, C. M. (1997). Coccoid forms of Helicobacter pylori are the morphologic manifestation of cell death. Infect Immun 65, 3672-3679.

Kwon, D. H., El-Zaatari, F. A., Kato, M., Osato, M. S., Reddy, R., Yamaoka, Y. \& Graham, D. Y. (2000a). Analysis of $r d x A$ and involvement of additional genes encoding $\mathrm{NAD}(\mathrm{P}) \mathrm{H}$ flavin oxidoreductase (FrxA) and ferredoxin-like protein $(\mathrm{FdxB})$ in metronidazole resistance of Helicobacter pylori. Antimicrob Agents Chemother 44, 2133-2142.

Kwon, D. H., Kato, M., El-Zaatari, F. A., Osato, M. S. \& Graham, D. Y. (2000b). Frame-shift mutations in NAD(P)H flavin oxidoreductase encoding gene $(f r x A)$ from metronidazole resistant Helicobacter pylori ATCC43504 and its involvement in metronidazole resistance. FEMS Microbiol Lett 188, 197-202.
Kwon, D. H., Hulten, K., Kato, M., Kim, J. J., Lee, M., El-Zaatari, F. A. Osato, M. S. \& Graham, D. Y. (2001). DNA sequence analysis of $r d x A$ and frxA from 12 pairs of metronidazole-sensitive and -resistant clinical Helicobacter pylori isolates. Antimicrob Agents Chemother 45, 26092615.

Lacey, S. L., Moss, S. F. \& Taylor, G. W. (1993). Metronidazole uptake by sensitive and resistant isolates of Helicobacter pylori. J Antimicrob Chemother 32, 393-400.

Loffeld, R. J. \& Fijen, C. A. (2003). Antibiotic resistance of Helicobacter pylori: a cross-sectional study in consecutive patients, and relation to ethnicity. Clin Microbiol Infect 9, 600-604

Lopez-Brea, M., Martinez, M. J., Domingo, D. \& Alarcon, T. (2001). A 9 year study of clarithromycin and metronidazole resistance in Helicobacter pylori from Spanish children. J Antimicrob Chemother 48, 295-297.

Malfertheiner, P., Megraud, F., O'Morain, C., Hungin, A. P., Jones, R., Axon, A., Graham, D. Y. \& Tytgat, G. (2002). Current concepts in the management of Helicobacter pylori infection-the Maastricht 2-2000 Consensus Report. Aliment Pharmacol Ther 16, 167-180.

Sambrook, J., Fritsch, E. F. \& Maniatis, T. (1989). Molecular Cloning: a Laboratory Manual, 2nd edn. Cold Spring Harbor, New York: Cold Spring Harbor Laboratory.

Sisson, G., Goodwin, A., Raudonikiene, A., Hughes, N. J., Mukhopadhyay, A. K., Berg, D. E. \& Hoffman, P. S. (2002). Enzymes associated with reductive activation and action of nitazoxanide, nitrofurans, and metronidazole in Helicobacter pylori. Antimicrob Agents Chemother 46, $2116-2123$

Smith, M. A. \& Edwards, D. I. (1995). Redox potential and oxygen concentration as factors in the susceptibility of Helicobacter pylori to nitroheterocyclic drugs. J Antimicrob Chemother 35, 751-764.

Smith, M. A. \& Edwards, D. I. (1997). Oxygen scavenging, NADH oxidase and metronidazole resistance in Helicobacter pylori. J Antimicrob Chemother 39, 347-353.

Smith, M. A., Jorgensen, M. A., Mendz, G. L. \& Hazell, S. L. (1998). Metronidazole resistance and microaerophily in Campylobacter species. Arch Microbiol 170, 279-284.

Sugiyama, T., Sakaki, N., Kozawa, H. \& 8 other authors (2002). Sensitivity of biopsy site in evaluating regression of gastric atrophy after Helicobacter pylori eradication treatment. Aliment Pharmacol Ther $\mathbf{1 6}$ Suppl. 2, 187-190.

Tomb, J. F., White, O., Kerlavage, A. R. \& 39 other authors (1997). The complete genome sequence of the gastric pathogen Helicobacter pylori. Nature 388, 539-547.

Trieber, C. A. \& Taylor, D. E. (2002). Mutations in the 16 S rRNA genes of Helicobacter pylori mediate resistance to tetracycline. J Bacteriol $\mathbf{1 8 4}$, $2131-2140$

van der Hulst, R. W., Keller, J. J., Rauws, E. A. \& Tytgat, G. N. (1996). Treatment of Helicobacter pylori infection: a review of the world literature. Helicobacter 1, 6-19.

van der Wouden, E. J., Thijs, J. C., van Zwet, A. A., Sluiter, W. J. \& Kleibeuker, J. H. (1999). The influence of in vitro nitroimidazole resistance on the efficacy of nitroimidazole-containing anti-Helicobacter pylori regimens: a meta-analysis. Am J Gastroenterol 94, 1751-1759.

Wilhelmsen, I. \& Berstad, A. (1994). Quality of life and relapse of duodenal ulcer before and after eradication of Helicobacter pylori. Scand J Gastroenterol 29, 874-879. 